\title{
DETERMINATION OF OCHRATOXIN A IN BABY FOODS BY ELISA AND HPLC
}

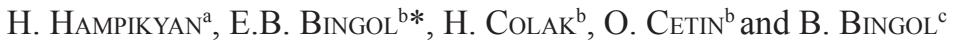

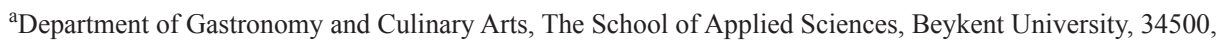 \\ Istanbul. Turkey \\ ${ }^{b}$ Department of Food Hygiene and Technology, Faculty of Veterinary Medicine, Istanbul University, 34320 , \\ Istanbul. Turkey \\ ${ }^{\mathrm{c}}$ Nobel Pharmaceutical, Inkilap Mah., Akcakoca Sok., No.10, Umraniye, 34768, Istanbul. Turkey
}

(Received: 14 May 2014; accepted: 2 July 2014)

\begin{abstract}
Ochratoxin A, is a well-known nephrotoxic, hepatotoxic and carcinogenic mycotoxin, produced by some species of mould genera such as Aspergillus spp. and Penicillium spp. under various environmental conditions, such as moisture and temperature. The main sources of Ochratoxin A intake for humans are cereals and cereal derived products, when they are consumed in large quantities, as in the case of breakfast cereals and cereal based baby foods principally consumed by babies. In this study, a total of 150 samples ( 50 infant formulas, 50 follow-on formulas, and 50 cereal based supplementary foods for infants and children) were obtained randomly from various supermarkets and pharmacies in Istanbul, and 52 out of 150 (34.7\%) analysed samples were contaminated with Ochratoxin A. None of the examined baby food samples were above the Turkish Food Codex maximum limit of Ochratoxin A in baby, infant, and young children foods $\left(0.5 \mu \mathrm{g} \mathrm{kg}^{-1}\right)$. These results reinforce the idea of strict and routine quality controls and good hygiene practices have to be performed in every step of production to minimize the potential risk of Ochratoxin A contamination.
\end{abstract}

Keywords: ochratoxin A, OTA, cereal, baby food, ELISA, HPLC

Ochratoxin A (OTA), 7-(- - $-\beta$-phenylalanyl-carbonyl)-carboxyl-5-chloro-8-hydroxy-3,4dihydro-3R-methylisocumarin, is a well-known nephrotoxic, hepatotoxic, teratogenic and carcinogenic mycotoxin, produced by some species of mould genera, such as Aspergillus spp. (mainly A. ochraceus) and Penicillium spp. (mainly P. verrucosum), depending on various environmental conditions like moisture, temperature, incubation time, and competitive flora (RAmos et al., 1998; EUROPEAN COMMISSION, 2002a; LeITNER et al., 2002; ABDULKADAR et al., 2004).

The presence of OTA in cereals (especially wheat), spices, dried fruits, and coffee is widespread in many countries during postharvest and storage period. Since OTA is a moderately stable molecule that can be found in foods during production, it naturally appears in processed products, such as beer, wine, coffee animal originated food derivatives, and cereal products (Albert \& Gauchi, 2002; Araguas et al., 2005; Ghali et al., 2009; Oruç et al., 2012; SEKKIN \& Kum, 2013).

In humans, the consumption of OTA contaminated products is suspected to be involved in the occurrence of Balkan Endemic Nephropathy (BEN), a fatal kidney disease, and also associated with urinary tract tumours in different parts of South-Eastern Europe (VISCONTI et al., 1999; El Khoury et al., 2008; ZaIed et al., 2011). The main source of OTA intake in humans is cereals: breakfast cereals, other cereal derived products, and cereal based baby

* To whom correspondence should be addressed. Phone: +90-212-47377171; fax: +90-212-47377171; e-mail: bingolb@istanbul.edu.tr 
foods. Especially infants are considered as a sensitive group of the population and they are more susceptible to mycotoxin exposure than adults, due to restricted diet rich in cereals and they consume more foods on a body weight (BW) basis than adults (EUROPEAN COMMISSION, 2002b; BRERA et al., 2011).

Many countries have specific regulatory or guideline limits for OTA in several food commodities. In the EU and Turkey, the maximum tolerable levels of OTA are set to 5 $\mu \mathrm{g} \mathrm{kg}^{-1}$ for cereals, $3 \mu \mathrm{g} \mathrm{kg}^{-1}$ for cereal derived products, and special attention has been paid to foods for infants and young children, where a more restrictive level has been set at $0.5 \mu \mathrm{g} \mathrm{kg}^{-1}$ (EUROPEAN COMMISSION, 2006a; TFC, 2008).

In recent years, in order to protect the consumer's health from the risk of exposure to OTA, rapid and reliable methods are necessary. For this purpose, the most commonly used specific and sensitive analytical method for the determination of OTA in cereal derived food products is high performance liquid chromatography (HPLC) with fluorescence detection after the immunoaffinity clean-up procedure. Even though this method is suggested by several authorities, the main disadvantages of HPLC are time consuming sample cleanup and consumption of large sample volumes. In contrast to HPLC, enzyme-linked immunosorbent assay (ELISA) is a rapid and simple method that requires low volume samples, but may sometimes result in systematic overestimate if compared to the chromatographic methods (BELli et al., 2002).

This situation adds a special interest to OTA in cereal derived products, and the aim of this study is to determine the presence of OTA by using ELISA and HPLC methods in baby foods sold in Istanbul-Turkey.

\section{Materials and methods}

\subsection{Sample collections}

In this study a total of 150 samples with original packaging, including 50 infant formulas, 50 follow-on formulas, and 50 cereal based supplementary foods for infants and young children were obtained randomly from various supermarkets and pharmacies in Istanbul.

\subsection{ELISA analysis}

1.2.1. Sample preparation. According to Ridascreen Ochratoxin Column manual (R-BIopharm, 2003), $10 \mathrm{~g}$ of sample was weighted in a vial, $20 \mathrm{ml}$ of acetonitrile/water was added, and it was mixed for $20 \mathrm{~min}$. After that, the solution was filtered and $5 \mathrm{ml}$ of filtrate was degreased with $5 \mathrm{ml}$ of $n$-heptane. The mixture was centrifuged $(5 \mathrm{~min} / 3000 \mathrm{~g} / \mathrm{room}$ temperature) and at the end of the process the upper heptane layer has been removed completely. Two millilitres of defatted filtrate was diluted with $13 \mathrm{ml}$ of PBS.

1.2.2. Extraction, clean up, and test procedure. The extraction, clean up, and test procedures were performed according to enzyme immunoassay for the quantitative analysis of Ochratoxin A, R-Biopharm Test Manuel (R-Biopharm, 2007).

\subsection{HPLC analysis}

1.3.1. Sample preparation and chromatographic conditions. OTA extraction in infant formulas, follow-on formulas, and cereal based supplementary foods for infants and young 
children was performed according to the AOAC Official Method 2000.03 (ENTwisLE et al., 2000 ) with slight modifications. A $25 \mathrm{~g}$ of sample was extracted with $100 \mathrm{ml}$ of acetonitrile:water (60:40, v/v) by mixing with Ultra-Turrax (IKA T18 Basic Ultra-Turrax, Germany) at 3500 r.p.m. for $2 \mathrm{~min}$ and centrifuged (Eppendorf, Centrifuge 5810R, Germany) at 4000 r.p.m. for $5 \mathrm{~min}$. The extract was filtered through Whatman No.1 filter paper. Then $10 \mathrm{ml}$ of the filtrate was diluted with $40 \mathrm{ml}$ of Phosphate-Buffered Saline (PBS, Oxoid BR0014, UK) solution. Final volume of $50 \mathrm{ml}$ eluate was passed through the immunoaffinity columns (OchraTest ${ }^{\mathrm{TM}}$, Vicam, Watertown, MA, USA) at 1-2 drop s ${ }^{-1}$ flow rate. The column was then washed with $10 \mathrm{ml}$ of PBS followed by $10 \mathrm{ml}$ of water, and OTA was eluted with $4 \mathrm{ml}$ of methanol. Then the eluate was evaporated to dryness under a gentle stream of nitrogen at $45^{\circ} \mathrm{C}$. The residue was re-dissolved in $1 \mathrm{ml}$ methanol and injected onto the HPLC system (Hewlett Packard 110 HPLC Chromatograph, equipped with a Hewlett Packard 1100 fluorescence detector) operating at the excitation and emission wavelengths of 333 and $460 \mathrm{~nm}$, respectively. The eluate passes through a Supelcosil LC-18 DB $(150 \mathrm{~mm} \times 4.6 \mathrm{~mm}, 3 \mu \mathrm{m})$ chromatographic column. The mobile phase was acetonitrile:water:acetic acid $(47 / 51 / 2, \mathrm{v} / \mathrm{v} / \mathrm{v})$ and the flow rate was set at $1 \mathrm{ml} \mathrm{min}^{-1}$.

Quantification of OTA was performed automatically by the computer according to the peak areas and their retention times, and by comparing them with their relevant standard calibration curve.

1.3.2. Quality control and quality assurance. The performance of extraction and cleanup procedure was confirmed by recovery practices. For this purpose, OTA-free formula samples were homogenised with deionised water $(10 \%)$ and spiked with OTA standard solutions at levels of $0.025,0.05,0.1,0.5$, and $1 \mu \mathrm{g} \mathrm{ml}^{-1}$. The spiked samples were stored in refrigerator $\left(4^{\circ} \mathrm{C}\right)$ for $6 \mathrm{~h}$ and analysed with HPLC according to the above-described test procedure. The experiment was performed in triplicate on the same day and the precision of method was calculated in terms of repeatability with relative standard deviation (RSD) by three-replicated analysis of the samples. The average recoveries were between $80 \pm 4.78$ and $89.1 \pm 5.63 \%$ for spiking levels ranging 0.025 to $1 \mu \mathrm{g} \mathrm{ml}^{-1}$. The RSD range for recoveries of OTA was $4.46-6.44 \%$ at the mentioned spiking levels (Table 1). According to the EU legislation, it is declared that recovery values for OTA are $70-110 \%$ at the concentration range of $1-10 \mu \mathrm{g} \mathrm{ml}^{-1}$. Obtained recovery values in the present study for OTA are within the requirements of the Regulation (EC) 401/2006 (EUROPEAN COMMISSION, 2006b).

Table 1. Performance parameters of the analytical methods for OTA

\begin{tabular}{lcccccc}
\hline $\begin{array}{l}\text { Spiking } \\
\text { level } \\
\left(\mu \mathrm{g} \mathrm{kg}^{-1}\right)\end{array}$ & $\begin{array}{c}\text { Mean amount } \\
\text { of recovery }\end{array}$ & $\begin{array}{c}\text { ELISA } \\
\text { Mean } \\
\text { recovery } \\
(\% \text { mean } \pm \text { SD })\end{array}$ & $\begin{array}{c}\text { CV } \\
(\%)\end{array}$ & $\begin{array}{c}\text { Mean amount } \\
\text { of recovery }\end{array}$ & $\begin{array}{c}\text { Mean } \\
\text { recovery } \\
(\% \text { mean } \pm \text { SD })\end{array}$ & $\begin{array}{c}\text { RSD } \\
(\%)\end{array}$ \\
\hline 0.025 & 0.022 & $88.0 \pm 6.48$ & 7.36 & 0.020 & $80.0 \pm 4.78$ & 5.98 \\
0.05 & 0.046 & $92.0 \pm 7.46$ & 8.10 & 0.042 & $84.0 \pm 5.41$ & 6.44 \\
0.1 & 0.093 & $93.0 \pm 8.12$ & 8.73 & 0.088 & $88.0 \pm 3.92$ & 4.46 \\
0.5 & 0.466 & $93.2 \pm 6.76$ & 7.25 & 0.438 & $87.6 \pm 4.58$ & 5.23 \\
1 & 0.949 & $94.9 \pm 7.81$ & 8.22 & 0.891 & $89.1 \pm 5.63$ & 6.32 \\
\hline
\end{tabular}

SD: Standard deviation; RSD: relative standard deviation; CV: coefficient of variation 
The standard curve was linear with a determination coefficient $\left(\mathrm{R}^{2}\right)$ of 0.98973 for OTA. The sensitivity was expressed in terms of limit of detection (LOD) and limit of quantification (LOQ) calculated as signal-to-noise (S/N) ratio of 3 and 10, and the chromatographic method were identified as $0.006 \mu \mathrm{g} \mathrm{kg}^{-1}$ and $0.019 \mu \mathrm{g} \mathrm{kg}^{-1}$ for OTA, respectively.

\subsection{Statistical analysis}

The concentrations of OTA in infant formulae, follow-on formulae, and cereal based supplementary foods for infants and young children samples were statistically analyzed and given as mean and standard deviation using SPSS 16.0 software (SPSS, 2008). The coefficients of determination $\left(\mathrm{R}^{2}\right)$, defined by regression/correlation analysis and OTA concentration detected by ELISA and HPLC, were compared using paired-samples $t$-test at $95 \%$ significance.

\section{Results and discussion}

The presence of OTA in baby foods was detected by using ELISA a rapid screening method, and the positive samples were confirmed by HPLC, which is a sensitive, accurate, and reliable technique. The distribution and evaluation of OTA amount values of analysed samples are given in Table 2 and Table 3, respectively.

Table 2. Distribution of OTA levels in baby food samples by ELISA

\begin{tabular}{lccccc}
\hline $\begin{array}{l}\text { Samples range } \\
\left(\mu \mathrm{g} \mathrm{kg}^{-1}\right)\end{array}$ & $\begin{array}{c}\text { Infant } \\
\text { formulae } \\
(\mathrm{n}=50)\end{array}$ & $\begin{array}{c}\text { Follow-on } \\
\text { formulae } \\
(\mathrm{n}=50)\end{array}$ & $\begin{array}{c}\text { Cereal based supplementary } \\
\text { foods for infants and young } \\
\text { children } \\
(\mathrm{n}=50)\end{array}$ & Total & $\%$ \\
\hline $\mathrm{ND}^{*}(<0.025)$ & 42 & 40 & 16 & 98 & 65.3 \\
$0.025-0.05$ & 6 & 5 & 14 & 25 & 16.7 \\
$0.051-0.10$ & 2 & 3 & 6 & 7 & 7.3 \\
$0.11-0.20$ & - & 2 & 5 & 4 & 4.7 \\
$0.21-0.30$ & - & - & 4 & 5 & 3.3 \\
$0.31-0.40$ & - & - & - & - & - \\
$0.41-0.50$ & - & - & - & - & - \\
$>0.50$ & - & - & - & & - \\
\hline
\end{tabular}

*ND: Not detected. Detection limit $0.025 \mu \mathrm{g} \mathrm{kg}^{-1}$

In this study, 52 out of 150 baby food samples $(34.7 \%)$ were found to be contaminated with OTA in the range of $0.027-0.38 \mu \mathrm{g} \mathrm{kg}^{-1}$ with ELISA, but none of the examined baby food samples were above the maximum limit of OTA of the Turkish Food Codex (TFC, 2008) in baby, infant, and young children food $\left(0.5 \mu \mathrm{g} \mathrm{kg}^{-1}\right)$. Also, these positive samples $(52 / 150$ baby foods) were confirmed by HPLC, and the detected OTA levels in infant formulae, follow-on formulae, and cereal based supplementary foods for infants and young children were between $0.026-0.089,0.022-0.178$, and $0.034-0.374 \mu \mathrm{g} \mathrm{kg}{ }^{-1}$, respectively. These results were closely similar to ELISA but significantly different $(\mathrm{P}<0.001)$. The difference of mean range between ELISA and HPLC were found to be $0.006(0.075 \%)$ for infant formulae, $0.007(0.07 \%)$ for follow-on formulae, and $0.07(0.20 \%)$ for cereal based supplementary foods for infants and young children (Table 3 ). 
Table 3. Evaluation of OTA levels in baby foods by ELISA and HPLC.

\begin{tabular}{|c|c|c|c|c|c|c|c|}
\hline \multirow{3}{*}{ Baby Foods Type } & \multirow{3}{*}{$\mathrm{n}$} & \multicolumn{3}{|c|}{ ELISA } & \multicolumn{3}{|c|}{ HPLC } \\
\hline & & \multicolumn{3}{|c|}{ Positive samples } & \multicolumn{3}{|c|}{ Positive samples } \\
\hline & & Number (\%) & Range $^{\mathrm{a}}$ & $\operatorname{Mean} \pm \mathrm{SD}^{\mathrm{b}, \mathrm{c}}$ & Number (\%) & Range $^{\mathrm{a}}$ & Mean $\pm \mathrm{SD}^{\mathrm{b}, \mathrm{c}}$ \\
\hline Infant formulae & 50 & $8(16)$ & $0.032-0.096$ & $0.043 \pm 0.8$ & $8(16)$ & $0.026-0.089$ & $0.037 \pm 0.6$ \\
\hline $\begin{array}{l}\text { Follow-on } \\
\text { formulae }\end{array}$ & 50 & $10(20)$ & $0.027-0.187$ & $0.089 \pm 0.5$ & $10(20)$ & $0.022-0.178$ & $0.082 \pm 0.4$ \\
\hline $\begin{array}{l}\text { Cereal based } \\
\text { supplementary } \\
\text { foods for infants } \\
\text { and young } \\
\text { children }\end{array}$ & 50 & $34(68)$ & $0.042-0.380$ & $0.16 \pm 0.7$ & $34(68)$ & $0.034-0.374$ & $0.09 \pm 0.3$ \\
\hline
\end{tabular}

$\mathrm{n}$ : Number of analysed samples; ${ }^{a}$ : minimum-maximum values $\left(\mu \mathrm{g} \mathrm{kg}^{-1}\right)$; ${ }^{\text {b}}$ : mean values $\left(\mu \mathrm{g} \mathrm{kg}^{-1}\right) \pm \mathrm{standard}$ deviation; ${ }^{c}$ : means within the raw are significantly different $(\mathrm{P}<0.001)$

Because the presence of OTA in baby foods is extremely hazardous to children, a number of studies have been carried out in different countries, and also in Turkey, to obtain a pattern of OTA contamination in baby foods. BAYDAR and co-workers (2007) determined that the total of 63 infant, follow-on, and baby food samples were contaminated with OTA in a range of $0.27-4.50 \mu \mathrm{g} \mathrm{kg}^{-1}$. In another study performed in Turkey by OzDEN and co-workers (2012), OTA was detected in 4 out of $21(19.05 \%)$ cereal based baby foods at the concentrations of $0.08-0.20 \mu \mathrm{g} \mathrm{kg}^{-1}$. In a similar research carried out by KABAK (2009), it was found that 4 out of $24(17.0 \%)$ cereal based baby foods contained OTA ranging from 0.122 to $0.374 \mu \mathrm{g} \mathrm{kg}^{-1}$. Our study agrees with the statement of KABAK (2012), who determined OTA in 2 follow-on formulae samples out of $36(5.6 \%)$ and in 10 toddler formulae samples out of $20(50 \%)$ in the range of $0.017-0.029 \mu \mathrm{g} \mathrm{kg}^{-1}$ and $0.024-0.184 \mu \mathrm{g} \mathrm{kg}{ }^{-1}$, respectively. In the light of these findings, it is obvious that developing technology in food manufacturing reduces the contamination of OTA in baby foods.

Furthermore, many surveys of OTA contamination in cereal based baby foods are available in the literature worldwide. LOMBAERT and co-workers (2003) announced that 42 out of 161 cereal based infant foods were contaminated with OTA up to $6.9 \mu \mathrm{g} \mathrm{kg}^{-1}$. However, BERETTA and co-workers (2002) found that 20 of 119 baby food samples contained OTA ranged from $<0.06$ to $0.74 \mu \mathrm{g} \mathrm{kg}^{-1}$. ARAGUAS and co-workers (2005) reported that 14 out of $20(70 \%)$ cereal based baby foods contained OTA up to $0.740 \mu \mathrm{g} \mathrm{kg}^{-1}$. AKSENOv and coworkers (2006) demonstrated that OTA occurred in $22.5 \%$ of 40 baby food samples with a mean level of $0.31 \mu \mathrm{g} \mathrm{kg}^{-1}$, and the researcher underlined that the levels were high especially in oat-based samples. BIFFI and co-workers (2004) stated that 4 baby food samples contained OTA above the Italian permitted maximum level of $0.5 \mu \mathrm{g} \mathrm{kg}^{-1}$. Contrary to this, JUAN and co-workers (2014) indicated that OTA was detected in $60 \%$ of cereal-based baby food samples at levels ranging from 0.05 to $0.120 \mathrm{mg} \mathrm{kg}^{-1}$. On the other hand, ZinEDINE and coworkers (2010) from MoROCCO reported that none of the 20 examined samples of baby foods were contaminated by OTA.

According to reports of Joint FAO/WHO Expert Committee of Food Additives (JECFA, 2001) and European Food Safety Authority (EFSA, 2006), the tolerable weekly intake of OTA is $100 \mathrm{ng} \mathrm{kg}^{-1}$ (14.2 $\mathrm{ng} \mathrm{kg} \mathrm{kg}^{-1} \mathrm{BW}$ per day) and $120 \mathrm{ng} \mathrm{kg} \mathrm{g}^{-1}\left(17.1 \mathrm{ng} \mathrm{kg}^{-1} \mathrm{BW}\right.$ per day), respectively. Based on these reports, in case a 9-month-old infant with BW of $8.5 \mathrm{~kg}$ consumes 
daily $\sim 50 \mathrm{~g}$ of cereal based baby food containing $0.38 \mu \mathrm{g} \mathrm{kg}^{-1}$ OTA (the highest OTA level detected in this study), the maximum daily intake would be $2.23 \mathrm{ng} \mathrm{kg}^{-1} \mathrm{BW}$. The present value is quite below the provisional tolerable daily intake. In light of these data, there is no significant health risk for infants, who occasionally consume baby food containing the detected levels of OTA in this study.

\section{Conclusion}

In conclusion, it is important to consider that cereals are the main sources of OTA intake for humans, and also it is known that cereal based baby formulas are basic foods for infants. These situations reinforce the idea of strict and routine quality control and good hygiene practices have to be performed at every step of production to minimize the potential risk of OTA contamination. In addition to this, periodic surveys should be carried out on the presence of mycotoxins, especially OTA, in cereal based baby foods in order to prevent the risk of exposure of infants to this toxin. These periodic controls can be performed both by ELISA and HPLC, which are useful methods for the detection of OTA. Though, HPLC is the more reliable method, ELISA enables us to analyse rapidly and easily large numbers of samples in routine screening.

This study was supported by the research fund of Istanbul University. Project number: 13932.

\section{References}

Abdulkadar, A.H.W., Al-Ali, A.A., Al-Kildi, A.M. \& Al-Jedah, J.H. (2004): Mycotoxins in foods products available in Qatar. Food Control, 15, 543-548.

Aksenov, I.V., Eller, K.I. \& Tutel'ian, V.A. (2006): Ochratoxin A content in baby foods. Vopr. Pitan., 74(5), 66-69.

Albert, I. \& Gauchi, J.P. (2002): Sensitivity analysis for high quantiles of ochratoxin A exposure distribution. Int. J. Food Microbiol., 75, 143-155.

Araguas, C., Penas, E.G. \& Lopez, C. (2005): A study on ochratoxin A in cereal-derived products from Spain. Food Chem., 92, 459-464.

Baydar, T., Erkekoglu, P., Sipahi, H. \& Sahin, G. (2007): Aflatoxin B1, M1 and ochratoxin A levels in infant formulae and baby foods marketed in Ankara, Turkey. J. Food Drug Anal., 15, 89-92.

Belli, N., Marin, S., SAnchis, V. \& Ramos, A.J. (2002): Review: Ochratoxin A (OTA) in wines, musts and grape juices: Occurrence, regulations and methods of analysis. Food Sci. Technol. Int., 8, 325-335.

Beretta, B., De Domenico, R., Gaiaschi, A., Ballabio, C., Galli, C.L., Gigliotti, C. \& Restani, P. (2002): Ochratoxin A in cereal based baby foods: occurrence and safety evaluation. Food Addit. Contam., 19, 70-75.

Biffi, R., Munari, M., Dioguardi, L., Ballabio, C., Cattaneo, A., Galli, C.L. \& Restani, P. (2004): Ochratoxin A in conventional and organic cereal derivatives: a survey of the Italian market, 2001-2002. Food Addit. Contam., $21,586-591$.

Brera, C., Debegnach, F., De santis, B., Pannunzi, E., Berdini, C., Prantera, E., Gregori, E. \& Miraglia, M. (2011): Simultaneous determination of aflatoxins and ochratoxin A in baby foods and paprika by HPLC with fluorescence detection: A single-laboratory validation study. Talanta, 83, 1442-1446.

EFSA (2006): European Food Safety Authority. Opinion of the scientific panel on contaminants in the food chain on a request from the commission related to ochratoxin A in food (question no. EFSA-Q-2005-154). The EFSA J. 365, 1-56.

El Khoury, A., Rizk, T., Lteif, R., Azouri, H., Delia, M.L. \& Lebrini, A. (2008): Fungal contamination and Aflatoxin B1 and Ochratoxin A in Lebanese wine-grapes and musts. Food Chem. Toxicol., 46, 2244-2250.

Entwisle, A.C., Williams, A.C., Mann, P.J., Slack, P.T. \& Gilbert, J. (2000): Liquid chromatographic method with immunoaffinity column clean-up for determination of ochratoxin A in barley: Collaborative study. J. AOAC Int., 83, 1377-1383. 
EUROPEAN COMMISSION (2002a): Commission Regulation No 472/2002 of 12 March 2002 amending Regulation (EC) No 466/2001 setting maximum levels for certain contaminants in foodstuffs. Off. J. Eur. Union, $L 75$ of 16.3 .2002

EUROPEAN COMMISSION (2002b): Report of experts participating in Task 3.2.7. Assessment of dietary intake of Ochratoxin A by the population of EU Member States. Directorate-General Health and Consumer Protection. http://ec.europa.eu/food/fs/scoop/3.2.7 en.pdf (last accessed 14 May 2014)

EUROPEAN COMMISSION (2006a): Commission Regulation (EC) No 1881/2006 of 19 December 2006 setting maximum levels for certain contaminants in foodstuffs. Off. J. Eur. Union, L3 64/5 - 364/24.

EUROPEAN COMMISSION (2006b): Commission regulation (EC) No 401/2006 of 23 February 2006 laying down the methods of sampling and analysis for the official control of the levels of mycotoxins in foodstuffs. Off. $J$. Eur. Union, L70, 12-34.

Ghali, R., Hmaissia-khlifa, K., Ghorbel, H., Maaroufi, K. \& Hedili, A. (2009): HPLC determination of ochratoxin A in high consumption Tunisian foods. Food Control, 20, 716-720.

JECFA (2001): Joint FAO/WHO Expert Committee of Food Additives. Ochratoxin A, -in: Safety evaluations of specific mycotoxins. Prepared by the 67th meeting of the joint FAO/WHO Expert Committee on Food Additives. Geneva.

Juan, C., Raiola, A., Mañes, J. \& Ritieni, A. (2014): Presence of mycotoxin in commercial infant formulas and baby foods from Italian market. Food Control, 39, 227-236.

KaBAK, B. (2009): Ochratoxin A in cereal-derived products in Turkey: Occurrence and exposure assessment. Food Chem Toxicol., 47, 348-352.

KABAK, B. (2012): Aflatoxin M1 and ochratoxin A in baby formulae in Turkey: Occurrence and safety evaluation. Food Control, 26, 182-187.

Leitner, A., Zöllner, P., Paolillo, A., Stroka, J., Bouraoui, A.P., Jaborek, S., Anklam, E. \& Linner, W. (2002): Comparison of methods for the determination of ochratoxin A in wine. Anal. Chim. Acta., 453, 33-41.

Lombaert, G.A., Pellaers, P., Roscoe, V., Mankotia, M., Neil, R. \& Scott, P.M. (2003): Mycotoxins in infant cereal foods from the Canadian retail market. Food Addit. Contam., 20, 494-504.

Oruç, H.H., Sorucu, A., Türkmen, I.I. \& Arslan, E. (2012): Determination of various mycotoxin concentrations in the feedstuffs and feed produced by a feed manufacturer in Turkey. Kafkas Univ Vet Fak Derg., 18, $633-638$.

Ozden, S., Akdeniz, A.S. \& Alpertunga, B. (2012): Occurrence of ochratoxin A in cereal-derived foods products commonly consumed in Turkey. Food Control, 25, 69-74.

Ramos, A.J., Labernia, N., Marin, S., Sanchis, V. \& Magan, N. (1998): Effect of water activity and temperature on growth and ochratoxin production by three strains of Aspergillus ochraceus on a barley extract medium and on barley grains. Int. J. Food Microbiol., 44, 133-140.

R-Biopharm (2003): Immunoaffinity column for sample clean up prior to analysis of Ochratoxin A, Art. No. R1303, R-Biopharm GmbH, Darmstadt, Germany.

R-Biopharm (2007): Enzyme immunoassay for the quantitative analysis of Ochratoxin A 30/15, Art. No. R1311, R-Biopharm GmbH, Darmstadt, Germany.

Sekkin, S. \& Kum, C. (2013): Possible natural toxins in organic livestock farming. Kafkas Univ Vet Fak Derg., 19, $725-734$.

SPSS (2008): Statistical package for the social sciences for Windows, Release no. 16.0, LEAD Technologies Inc.

TFC (2008): Turkish Food Codex. Legislation about determination of maximum levels of certain contaminants in foods. Basbakanlik Basimevi, Ankara, Turkey.

Visconti, A., Pascale, M. \& Centonze, G. (1999): Determination of ochratoxin A in wine by means of immunoaffinity column clean-up and high-performance liquid chromatography. J. Chromatogr. A., 864, 89-101.

Zaied, C., Bouaziz, C., Azizi, I., Bensassi, F., Chour, A., Bacha, H. \& Abid, S. (2011): Presence of ochratoxin A in Tunisian blood nephropathy patients. Exposure level to OTA. Exp. Toxicol. Pathol., 63, 613-618.

Zinedine, A., Blesa, J., Mahnine, E.L., Abidi, A., Montesano, D. \& Manes, J. (2010): Pressurized liquid extraction coupled to liquid chromatography for the analysis of ochratoxin A in breakfast and infants cereals from Morocco. Food Control, 21, 132-135. 